\title{
EVALUATION OF SOME INSECTICIDES ON INFESTATION OF RED PALM WEEVIL Rhynchophorus ferrugineus (OLIVIER) (COLEOPTERA: CURCULIONIDAE) \\ Abdel-Salam, A. H. ${ }^{1}$; A.A.EL-Bana ${ }^{2}$; and Eman E. H. El-Rehewy ${ }^{3}$ \\ 1-Economic Entomology Department, Faculty of Agriculture, Mansoura University, Egypt. E-mail: adhabdelus@yahoo.com \\ 2-Chief Researcher and Director of Date palm Research Laboratory- Vice President of Agricultural Research Center \\ 3-Plant Protection Research Institute, Agricultural Research Center, Dokki, Giza, Egypt. E-mail: emanelrehewy@yahoo.com
}

\begin{abstract}
The present work was carried out at El-Katta village to evaluate the efficiency of six synthetic insecticides (Pyriban $^{\circledR}$, keiton ${ }^{\circledR}$, Egycron, Fenthion ${ }^{\circledR}$, Fury ${ }^{\circledR}$, and Regent ${ }^{\circledR}$ ) and two bio-insecticide (Biovar $^{\circledR}$ (Beauveria bassiana) and Avermectin ${ }^{\circledR}$ (emamectin benzoate)). Insecticide solutions were injected into three holes against the immature stages of Red Palm Weevil (RPW), Rhynchophorus ferrugineus (Olivier) (Coleoptera: Curculionidae). Three concentrations of each tested insecticides $(0.3 \%$, 0.6 and $0.9 \%$ ) were used. The insecticides were applied at rate of one liter per tree. The numbers of recovery palm trees were investigated every week and recorded after forty five days from treatment. The obtained results showed that the most effective insecticide was Pyriban ${ }^{\circledR}$ and Keiton ${ }^{\circledR}(62.5 \%)$, followed by Egycron ${ }^{\circledR}(58.3 \%)$, Fenthion $^{\circledR}(37.5 \%)$, Fury ${ }^{\circledR}(29 \%)$, and Reagent ${ }^{\circledR}(25 \%)$. The bioagents were less effective than synthetic insecticides; Biovar ${ }^{\circledR}(12.5 \%)$ and Avermectin $^{\circledR}(4.1 \%)$ at $0.3 \%$ concentration.

Keywords: Red Palm Weevil, Rhynchophorus ferrugineus (Olivier), chemical insecticides, bio-insecticides, injection.
\end{abstract}

\section{INTRODUCTION}

The date palm and the date fruits are hosts for many insects and diseases which are seriously enough to inflict heavy losses if left without control. Under traditional date palm culture, the growers were helpless and in some cases they were unable to identify the causal organism. Date palm insect pests, in general, and the red palm weevil, Rhynchophorus ferrugineus (Olivier) (Coleoptera: Curculionidae), in particular, are widely accepted as being the most destructive factors of date, coconut and oil palms throughout South and Southeast Asia (Wattanapongsiri, 1966). Nowadays, the date palm crop in Eastern Arab countries is under threat. Red palm weevil was probably introduced to the Middle East on infested ornamental palm from Emerote. Red palm weevil was firstly discovered attacking palm in the Arabian peninsula especially United Emirates at 1986 and progressively spread to Gulf states and crossed the red sea into North Africa as the latest record since 1992 in Egypt. It is found over a wide geographical area in Asia, involving many different agro ecosystems. The related species is highly polyphagous with number of known hosts exceeding more than ten different palm species (Murphy and Briscoe, 1999). Effective methods for control this 
pest has been difficult to develop. During the last two decades all efforts to control $R$. ferrugineus in the Arab countries, focused on the use of traditional insecticides, modified cultural practices and recently pheromone traps (Abraham et al., 1998). The most effective control method is using chemical treatment by injection. In this method, all holes in the trunk of infested palm are plugged then, a hole just above the infested region is drilled and a suspension of insecticide poured into it (Kranz et al., 1978and Nair, 1986). Many reports were revealed the efficiency of the usage of this method (Abdallah and Al-Khatri, 2000; Girgis et al., 2002; El-Zemaity et al., 2010; and Saleh et al., 2012).

Because of the concealed nature of red palm weevil, effective methods for control this pest have been difficult to develop. Among various control tactics attempted against red palm weevil, chemical control is essential quick and reliable way of recovering infested date palm trees. The objectives of the present study were to evaluate the efficacy of six synthetic chemical insecticides and two bioinsecticides against the immature stages inside the holes in trunk date palm trees.

\section{MATERIALS AND METHODS}

\section{1-Tested compounds:}

Six synthetic insecticides; Pyriban ${ }^{\circledR}$ (Chloropyrifos $48 \%$ ), keiton ${ }^{\circledR}$ (Phenthoate), Egycron, Fenthion ${ }^{\circledR}$ (fenitrothion), Fury ${ }^{\circledR}$, and Regent ${ }^{\circledR}$ (fipronil), and two bioinsecticides; Biovar ${ }^{\left({ }^{(}\right.}$(Beauveria bassiana) and Avermectin ${ }^{\circledR}$ (emamectin benzoate) were used against the immature stages of the red palm weevil in infested palms. The tested compounds were applied in three concentrations $(0.3,0.6$, and $0.9 \%)$. These concentrations were prepared by diluting the tested insecticides in $1000 \mathrm{~cm}^{3}$.

\section{2-Experimental methods:}

The present study was carried in date palm field in El-Katta, Giza Governorate. Seven hundred and eighty date palm trees were chosen and divided into five replicates. Each replicate contained six date palms, each of which received one treatment of the tested compounds. Insecticide concentrations were prepared. Used concentrations were injected into the site of infestation inside the palm tree trunk. Untreated date palm trees were injected with $1000 \mathrm{~cm}^{3}$ water only. Recovered and non-recovered palm trees were counted and recorded after 45 days post injection. Observation the fluid oozed where from opaque or limpid, acrid odor or odorless (Girgis et al., 2002).

3-Data analysis:

- Infested palm trees were considered as recovered when:

- The fluid oozed was limpid and odor less.

-The obtained results were corrected according to Abbott's formula (Abbott, 1925).

Statistical analysis was calculated to differentiate between different treatments according to "F" test and L.S.D. (Fisher, 1950) using Costat statistics 6.0 , release 6.303 software. 


\section{RESULTS AND DISCUSSION}

Data represented in Table (1) showed the mean number of recovered date palm trees after treatment with different concentrations of the tested compounds. Results showed that the highest number of recovered trees was obtained when the date palm trees were treated with $\operatorname{Pyriben}^{\circledR}, \operatorname{Egycron}^{\circledR}$, and Keiton ${ }^{\circledR}$. Treatment of Avermectin ${ }^{\circledR}$ and Biovar ${ }^{\Theta}$ showed low number of recovered trees.

Table (1): Mean number ( \pm S. E.) of recovered date palm trees after injection with different concentrations of tested compounds

\begin{tabular}{|c|c|c|c|}
\hline \multirow{2}{*}{ Compounds } & \multicolumn{3}{|c|}{$\begin{array}{l}\text { Recovered palm trees after treatment with } \\
\text { concentration (Mean } \pm \text { S.E.) }\end{array}$} \\
\hline & $0.3 \%$ & $0.6 \%$ & $0.9 \%$ \\
\hline Regent $^{(\Theta}$ & $1.5 \pm 0.64^{\text {cd }}$ & $4.2 \pm 0.48^{\mathrm{ab}}$ & $4.7 \pm 0.25^{b}$ \\
\hline Fenthion $^{\circledR}$ & $2.2 \pm 0.48^{b c}$ & $2.7 \pm 0.48^{b}$ & $4.5 \pm 0.29^{b}$ \\
\hline Avermectin ${ }^{\Theta}$ & $0.25 \pm 0.25^{c}$ & $0.75 \pm 0.48^{\mathrm{c}}$ & $1.0 \pm 0.41^{\mathrm{c}}$ \\
\hline Fury ${ }^{\Theta}$ & $1.7 \pm 0.48^{\mathrm{C}}$ & $3.5 \pm 0.64^{\mathrm{ab}}$ & $3.7 \pm 0.48^{b}$ \\
\hline Eqycron $^{\Theta}$ & $3.5 \pm 0.29^{\text {ab }}$ & $4.2 \pm 0.48^{\mathrm{ab}}$ & $5.7 \pm 0.25^{a}$ \\
\hline Pyriban $^{\circledR}$ & $3.7 \pm 0.48^{\mathrm{a}}$ & $4.7 \pm 0.48^{\mathrm{a}}$ & $6.0 \pm 0.00^{a}$ \\
\hline Keiton ${ }^{\otimes}$ & $3.7 \pm 0.25^{\mathrm{a}}$ & $4.2 \pm 0.48^{\mathrm{ab}}$ & $4.7 \pm 0.48^{b}$ \\
\hline Biovar $^{(B)}$ & $0.75 \pm 0.78 c$ & $0.75 \pm 0.78^{\mathrm{C}}$ & $1.0 \pm 0.41^{\mathrm{C}}$ \\
\hline Untreated & $0.25 \pm 0.25^{\mathrm{d}}$ & $0.25 \pm 0.25^{d}$ & $0.0 \pm 0.0^{\mathrm{d}}$ \\
\hline
\end{tabular}

Results in Table (2) showed the efficacy of tested chemical insecticides and bioinsecticides against the immature stages of the red palm weevil infested palm trees. After treatment, it was noticed that oozing stopped in all infested palm trees as an indication of the efficacy of tested compounds. It was also noticed that the higher the concentration was the more recovered palm trees obtained. Results showed that the recovered palm trees were increased after treatment with Pyriban ${ }^{\circledR}$ and Egycron $^{\circledR}$ at concentration 0.9\% (100 and 95.8\%, respectively). Furthermore, treatment with Avermectin ${ }^{\circledR}$ and Biovar ${ }^{\circledR}$ showed low insecticidal efficacy in all used concentrations.

These results were consistent with Azam and Razvi (2001); Soliman and Abd El-Latif (2008); Abbas (2013) and Al-Dawood et al. (2013) who reported that trunk injection with different chemical insecticides showed complete recovery.

Meanwhile, the results were contradicting to Gindin et al. (2006), and El-Sufty et al. (2011) who reported that treatment of infested palm trees with $B$. bassiana at different concentrations caused high recovery rate.

In conclusion, chemical control can be an effective technique to control RPW in all stages when applied through injection. Further studies are recommended with uniform infestation level in quarantine green house. 
Table (2): Efficacy percentage of injected tested compounds

\begin{tabular}{|l|c|c|c|c|}
\hline \multirow{2}{*}{ Compounds } & \multicolumn{3}{|c|}{$\begin{array}{c}\text { \% efficacy of } \\
\text { concentration }\end{array}$} & \multirow{2}{*}{ Mean } \\
\cline { 2 - 4 } & $\mathbf{0 . 3 \%}$ & $\mathbf{0 . 6 \%}$ & $\mathbf{0 . 9 \%}$ & \\
\hline Regent $^{\circledR}$ & $25 \mathrm{c}$ & $70 \mathrm{a}$ & $\mathbf{7 9 a}$ & 58 \\
\hline Fenthion $^{\circledR}$ & $37.5 \mathrm{~b}$ & $\mathbf{4 5 . 8 \mathrm { b }}$ & $\mathbf{7 5 a}$ & 52.76 \\
\hline Avermectin $^{\circledR}$ & $4.1 \mathrm{c}$ & $12.5 \mathrm{c}$ & $16 \mathrm{c}$ & 10.866 \\
\hline Fury $^{\circledR}$ & $29 \mathrm{c}$ & $58 \mathrm{~b}$ & $62.5 \mathrm{a}$ & 49.833 \\
\hline Egycron $^{\circledR}$ & $58.3 \mathrm{~b}$ & $70 \mathrm{a}$ & $95.8 \mathrm{a}$ & 74.7 \\
\hline Pyriban $^{\circledR}$ & $62.5 \mathrm{a}$ & $79 \mathrm{a}$ & $100 \mathrm{a}$ & 80.53 \\
\hline Keiton $^{\circledR}$ & $62.5 \mathrm{a}$ & $70 \mathrm{a}$ & $79 \mathrm{a}$ & 70.5 \\
\hline Biovar $^{\circledR}$ & $12.5 \mathrm{c}$ & $12.5 \mathrm{c}$ & $16.6 \mathrm{c}$ & 13.866 \\
\hline
\end{tabular}

\section{REFERENCES}

Abbas, M. K. (2013). Evaluation methods for red palm weevil control in egypt during (1992-2010). AFPP-Palm pest Mediterranean conference NICE, 16-18 January, 2013.

Abbott, W. S. (1925). A method of computing the effectiveness of an insecticide. J. Econ. Entomol. 18: 265-267.

Abdallah, F. F. and Al-Khatri, S. A. (2000). The effectiveness of trunk injection and fumigation for the control of the red palm weevil, Rhynchophorus ferrugineus Olivier in date palm. J. Plant Prot. In the tropics, 13(1): 17-21.

Abraham, V. A.; Al-Shuaibi, M. A; Faleir, J. R.; Abouzhairah, R. A.; and Vidyasagar, P. S. P.V. (1998). An integrated management approach for red palm weevil, Rhynchophorus ferrugineus Olivier, a key pest of date palm in the Middle East. Sultan Qabus Univ., J. Sci. Res. Agric. Sci., 3: 77-84.

Aldawood, A. N.; Alsagan, F.; Altuwariqi, H.; Almuteri, A.; and Rasool, K. (2013). Red palm weevil chemical treatments on date palms in Saudi Arabia: results of extensive experimentations. In Colloque méditerranéen sur les ravageurs des palmiers, Nice, France, 16-18 Janvier 2013. Association Française de Protection des Plantes (AFPP).

Azam, K. M. and Razvi, S. S. (2001). Control of red palm weevil, Rhynchophorus ferrugineus Oliver using prophylactic spraying ofdate palms and trunk injection. Proc. Second International Conference on Date Palms (AI-Ain, UAE, March 25-27, 2001), 216-222.

El-Sufty, R.; Al Bgham, S.; Al-Awash, S. A.; Shahdad, A.; and Al Bathra, A. (2011). A trap for autodissemination of the entomopathogenic fungus Beauveria bassiana by Red Palm Weevil adults in date palm plantations. Egypt. J. Biol. Pest Co.; 21(2): 271-276.

El-Zemaity, M. S.; Abdel-Megeed, M. I.; Abdul-Wahed, M. S.; and Reda, A. A. (2010). Factors influencing the effectiveness of certain novel insecticides against red palm weevil. Acta. Hort. (ISHS) 882:923-927. 
Fisher,R. A.(1950). Statistical methods for research workers. Oliver and Boyd Ltd., Edinburgh, London.

Gindin, G.; Levski, S.; Glazer, I.; and Soroker, V. (2006). Evaluation of the entomopathogenic fungi Metarhizium anisopliae and Beauveria bassiana against the Red Palm Weevil Rhynchophorus ferrugineus. Phytoparasitica, 34: 370-379.

Girgis, G. N.; Batt, A. M.; Okil, A. M.; Haggag, S. M.; and Abdel Azim, M. M. (2002). Evaluation of trunk injection methods for the control of red palm weevil, Rhynchophorus ferrugineus (Oliver) in date palm trees in Egypt. $2^{\text {nd }}$ International Conference, Plant Protection Institute, Cairo, Egypt, 21-24 December 2002; 1: 709-711.

Kranz, J.; Schmutterer, H.; and Kock, W. (1978). Diseases, pests, and weeds in tropical crops. John Wiley \& Sons, N. Y. 410-412.

Murphy, S. and Briscoe, B. (1999). The red palm weevil as an alien invasive: biology and prospects for biological control as component of IPM. Biocontrol News and Information, 20(1): 35-46.

Nair, M. R. G. K. (1986). Insects and mites of crops in India. Publication and Information division, Indian council of agricultural research, New Delhi: 86-87.

Saleh, M. M. E.; Abdel- Monim, A. S. H.; and El-Kholy, M. Y. (2012). Population of adults of the red palm weevil, Rhynchophorus ferrugineus (Coleoptera: Curculionidae) in date palm farms in Ismailia governorate. Egypt. J. Am. Sci.; 8(12): 440-443.

Soliman, R. H. A. and Abd El-latif, N. A. (2008). Laboratory and field evaluation of insecticides against the olive beetle Phloeotribus scarabaeoides Bern. (Coleoptera: Scolytidae) in Fayoum, Egypt. Fayoum J.Agric. Res. \& Dev.; 22: 176-281.

Wattanapongsiri, A. (1966). A revision of the genera Rhynchophorus and dynamics (Coleoptera: Curculionidae). Dept. Agric. Sci. Bull. 1, Bangkok: 1-326 pp.

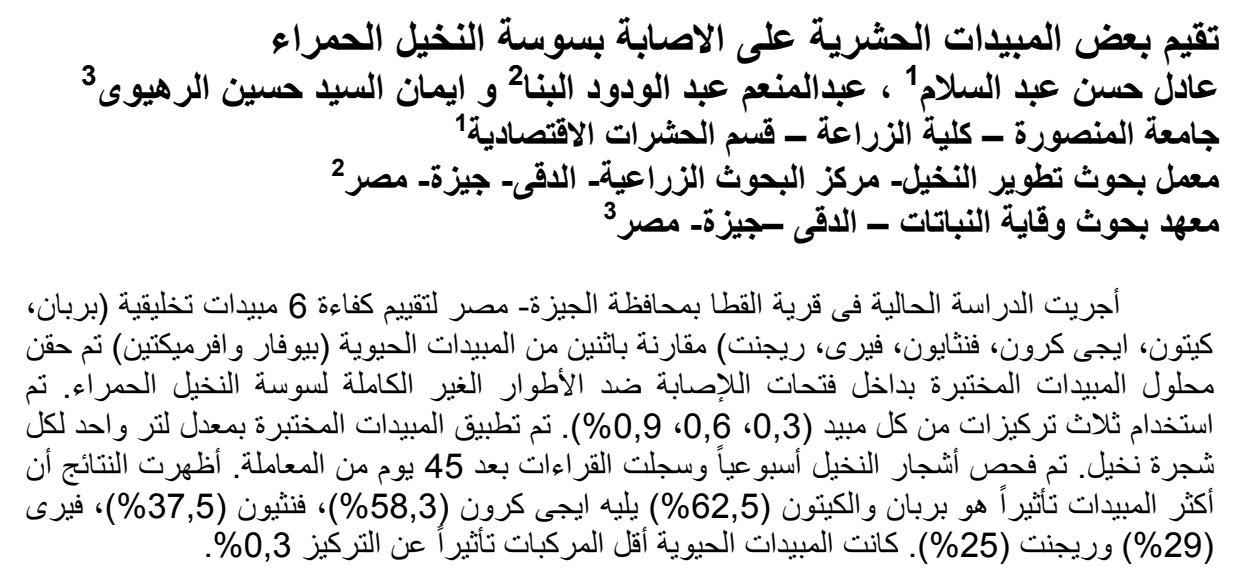

